Gelanggang Olahraga: Jurnal Pendidikan Jasmani dan Olahraga

Volume 2, Nomor 1, Juli-Desember 2018

e-ISSN : 2597-6567

p-ISSN : 2614-607X

DOI : https://doi.org/10.31539/jpjo.v2i1.423

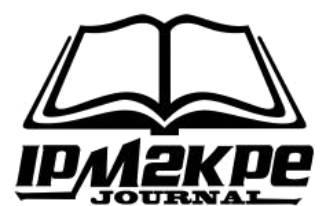

\title{
PENGARUH METODE LATIHAN PLYOMETRIC DAN LATIHAN BEBAN DENGAN KECEPATAN REAKSI TERHADAP POWER OTOT TUNGKAI PEMAIN BOLAVOLI PUTRA
}

\author{
Supriyanto \\ Program Studi Pendidikan Jasmani Kesehatan dan Rekreasi \\ Universitas Dehasen Bengkulu \\ supriyanto@unived.ac.id
}

\begin{abstract}
ABSTRAK
Tujuan penelitian ini adalah untuk mengetahui pengaruh metode latihan plyometric dan latihan beban dengan kecepatan reaksi terhadap power otot tungkai pemain bola voli Putra. Metode penelitian yang digunakan adalah desain treatment by level $2 \times 2$, di mana variabel bebas diklasifikasikan menjadi 2 (dua). Hasil penelitian, yakni (1) secara keseluruhan terdapat perbedaan pengaruh siqnifikan metode latihan plyometric dan latihan beban terhadap power otot tungkai pemain bola voli $\left(\mathrm{F}_{\mathrm{h}}=0,58<\mathrm{F}_{\mathrm{t}}=4,00\right)$, (2) terdapat interaksi antara metode latihan dan kecepatan reaksi terhadap power otot tungkai pemain bolavoli Putra SMA IT IQRO Kota Bengkulu $\left(F_{h}=28,39>F_{t}=3,97\right)$, (3) pemain bolavoli yang memiliki kecepatan reasksi tinggi memiliki power otot tungkai yang lebih baik jika dilatih dengan metode latihan Beban dari pada dilatih dengan metode latihan Plyometric $\left(\mathrm{F}_{\mathrm{h}}=5,35>\mathrm{F}_{\mathrm{t}}=4,01\right)$. 4. Pemain bolavoli yang memiliki kecepatan reaksi rendah memiliki power otot tungkai yang lebih baik jika dilatih dengan metode latihan plyometric dari pada dilatih dengan metode latihan beban $\left(f_{h}=5,12>f_{t}=4,01\right)$. Simpulan penelitian ini menjelaskan bahwa pemain yang memiliki kecepatan reaksi tinggi lebih efisien dilatih dengan metode latihan beban, sedangkan pemain yang memiliki kecepatan reaksi rendah lebih efisien dilatih dengan metode latihan plyometric
\end{abstract}

Kata kunci : Metode Latihan Plyometric, Kecepatan Reaksi, Power Otot Tungkai.

\section{ABSTRACT}

The purpose of this study was to know the effect of plyometric training and weight training with reaction speed toward limb muscle of male volleyball players. The method of the study was treatment design level $2 \times 2$, where the independent variable was classified in two parts. The findings were: (1) overall, there is different significant effect of plyometric training and weight training toward limb muscle power of volleyball players $(F h=0.58<F t=4.00)$, (2) there is interaction between training methods and reaction speed toward limb muscle power of male volleyball players of SMA IQRO IT Bengkulu city $(F h=28.39>F t$ = 3.97), (3) volleyball players who have high speed reaction have better limb muscle power if using training method rather than training with the Plyometric training method $(F h=5.35>F t=4.01)$. (4) Volleyball players who have low reaction speed have better limb muscle power if trained by weight training 
method $(f h=5.12>f t=4.01)$. In Conclusion, volleyball players who have high reaction speed are more efficient trained by weight training, meanwhile volleyball players who have low reaction speed are more efficient trained by plyometric training

Keyword: Plyometric Exercise Method, Reaction Speed, Power of Leg Muscles.

\section{PENDAHULUAN}

Olahraga dapat digunakan sebagai sarana menuju kesehatan, sebagai sarana rekreasi dan dapat sebagai prestasi. Olahraga sudah menjadi gaya hidup, misalkan di negara-negara maju setiap individu meluangkan waktu untuk melakukan kegiatan fisik atau melakukan aktivitas jasmani. Bentuk aktivitas bermacam-macam, bisa menghabiskan waktu di pusat kebugaran, dan bisa juga di taman-taman kota seperti melakukan jogging, dan untuk mencari kesenangan. Selain olahraga kesehatan dan olahraga rekreasi ada juga olahraga prestasi, salah satunya adalah olahraga prestasi cabang bolavoli.

Bolavoli merupakan salah satu cabang olahraga yang dimainkan oleh lakilaki maupun perempuan dari segala tingkatan usia. Oleh karena itu bolavoli cukup mempunyai banyak penggemar dan menggelutinya, dalam permainan bolavoli harus mempunyai keterampilan teknik,taktik dan kondisi fisik dan merupakan satu kesatuan yang saling mendukung.

Kondisi fisik dalam permainan bolavoli merupakan salah satu prasyarat yang sangat diperlukan dalam setiap usaha peningkatan prestasi. Kondisi fisik adalah satu kesatuan yang utuh dari komponen-komponen yang tidak dapat dipisahkan, baik peningkatannya maupun pemeliharaannya. Kondisi fisik antara lain daya tahan, kekuatan, kecepatan,dan daya ledak (power). Komponen kondisi fisik tersebut merupakan faktor utama dalam menunjang teknik dan taktik permainan. Komponen kekuatan menjadi dasar dari komponen-komponen yang lain.

Selain kecepatan reaksi dalam olahraga bolavoli membutuhkan kondisi fisik seperti power apabila seorang pemain mempunyai power yang baik maka pemain tersebut diduga akan lebih mudah mendapatkan poin. Dalam sebuah pertandingan dapat dilihat pemain tidak mampu mengembalikan bola atau sering tersangkut net. Dari permasalahan inilah diduga bahwa otot tungkai tidak memliki power yang bagus sedangkan tujuan dari permainan ini adalah mengumpulkan point melalui serangkaian pukulan-pukulan yang membuat lawan tidak mampu mengembalikan bola dengan baik, atau memaksa lawan kehilangan point.

Kondisi power otot tungkai untuk pemain masih perlu di kembangkan, karena masing-masing pemain memiliki power tungkai yang berbeda satu sama lain. Tahapan remaja menjadi dasar perkembangan pemain menuju kondisi puncak ketika dia memasuki level senior. Adanya pembinaan yang tepat melalui metode yang baik diharapkan dapat mengembangkan kempuan atlet dari segi fisik dalam hal ini power otot tungkai Ikhwanudin (2011)

SMA IT IQRO kota Bengkulu dalam proses belajar mengajar khususnya pembelajaran pendidikan jasmani telah diberikannya materi-materi pembelajaran olahraga untuk para siswa. Disamping pembelajarn formal, di SMA IT IQRO kota Bengkulu dalam meningkatkan kualitas bakat dan minat siswa-siswi baik dalam 
segi ilmu pengetahuan, seni, dan berolahraga, maka pihak sekolah membuat program latihan yang di sebut dengan ektrakurikuler (ekskul). Adapun cabang ekskul yang ada di SMA IT IQRO kota Bengkulu tersebut antara lain: tari, seni gambar, sains, dan lain-lain, dan dalam cabang olahraga antara lain: pencak silat, sepak bola, bulu tangkis, bolavoli, sepak takraw, bola basket, dan lain-lain. Diantara seluruh ekskul yang ada salah satu cabang ekskul yang sangat popular atau banyak diminati oleh para siswa di SMA IT IQRO kota Bengkulu adalah cabang olahraga bolavoli. Akan tetapi pembelajaran pada materi bola bolavoli ini masih sangat kurang untuk sebuah prestasi bolavoli. Selanjutnya pihak sekolah telah melakukan pembinaan dan pelatihan secara khusus untuk olahraga permainan bolavoli. Pelaksanaan proses latihan dilakukan sebanyak dua kali dalam satu minggu yaitu hari rabu, pukul 16.00-18.00 WIB, sedangkan hari jumad dilaksanakan mulai pukul 16.00-18.00 WIB. Kemudian dilatih langsung oleh seorang pelatih, dan latihan dilakukan di lapangan bolavoli di SMA IT IQRO kota Bengkulu. Akan tetapi, dikarenakan siswa yang mengikuti ekskul bolavoli di SMA IT IQRO kota Bengkulu masih kurang dalam memahami teknik dan pola permaianan bolavoli. Pembinaan dan pengembangan olahraga bolavoli ini diikuti oleh peserta didik putra yang memiliki bakat dan minat dalam olahraga bolavoli.

Dalam permainan bolavoli perlu didukung oleh komponen kondisi fisik, kemampuan teknik dan taktik serta yang terkait dengan masalah psikologis dan metode latihan yang terprogram dan motivasi berprestasi pemain yang baik. Metode latihan yang terprogram dan didukung dengan motivasi pemain yang baik akan berpengarauh dalam prestasi dalam olahraga. Tanpa didukung dengan kualitas program latihan yang baik dan pelatihan yang benar maka prestasi maksimal sulit untuk dicapai. Dan tidak lupa juga sarana dan prasarana yang mendukung untuk terlaksananya kegiatan ekskul bolavoli demi kelancaran dan terbinanya siswa yang mempunyai bakat dan minat, serta dukungan dari orang tua sangat berperan aktif dalam tercapainya bakat siswa tersebut.

Berdasarkan pengalaman dan pengamatan penulis, terlihat bahwa teknik dasar yang dilakukan oleh tim ekskul bolavoli di SMA IT IQRO kota Bengkulu masih jauh dari kesempurnaan, terlihat dari proses latihan yang dilaksanakan masih banyak teknik-teknik yang belum dikuasai oleh para pemain lainnya, terutama dalam melakukan tembakan smash. Teknik smash ini merupakan salah satu teknik menyerang dalam permainan bola voli yang harus di kuasai oleh setiap pemain. Dengan demikian, dari sekian banyak kelemahan, yang paling menonjol adalah kemampuan dalam melakukan smash. Untuk melakukan teknik smash seorang pemain harus memiliki kemampuan dalam daya ledak otot tungkai yang baik. Banyak metode latihan yang bisa diberikan seperti: standing vertical jump, tuck jump, buut kick jump, pike jump, box jump, static squat jump, box landing, lateral jump, lateral box jump, single leg box jump, push off dan latihan beban seperti halnya yang dilakukan oleh pelatih selama ini. Dari beberapa metode latihan tersebut belum diketahui dengan pasti metode mana yang paling efektif dan baik hasilnya untuk kemampuan hasil smash pada bolavoli.

Seperti yang diungkap oleh Siswantoyo (1996) dalam cabang pencak silat power otot tungkai memiliki persentase lebih besar sumbangannya, bila dibandingkan dengan unsur keseimbangan dan kecepatan (power tungkai $33 \%$, keseimbangan $13 \%$, dan kecepatan $26 \%$ ). Hal ini menunjukkan bahwa power otot tungkai juga sangat diperlukan dalam cabang olahraga beladiri terutama 
untuk melakukan tendangan. Begitu pula dalam cabang bolavoli, power tungkai merupakan komponen fisik yang dominan. Prinsip latihan plyometric dapat digunakan pada berbagai olahraga yang lain (Radcliffe dan Farentinos, 1985: 9). Dengan latihan plyometric seseorang dapat meningkatkan kekuatan, kecepatan, dan power melalui proses peregangan dan pemendekan serabut otot.

\section{KAJIAN TEORI}

Power merupakan perpaduan dua unsur komponen kondisi fisik yaitu kekuatan dan kecepatan. Kualitas power akan tercermin dari unsur kekuatan dan kecepatan yang dalam pelaksanaannya dilakukan dengan eksplosif dalam waktu yang sesingkat mungkin. Dalam ilmu keolahragaan power dapat juga disebut dengan daya ledak (Explosive Power) atau muscular power. Sajoto (1995) menyatakan bahwa "Daya ledak otot atau muscular power adalah kemampuan seseorang untuk melakukan kekuatan maksimum, dengan usaha yang dikerjakan dalam waktu yang sependek pendeknya. Dalam hal ini dinyatakan bahwa daya ledak otot adalah hasil perkalian antara kekuatan dan kecepatan". Hal senada dikemukakan oleh Sugiyanto \& Sudjarwo (1993) bahwa, "Power atau daya ledak eksplosif adalah kualitas yang memungkinkan kerja otot atau sekelompok otot untuk menghasilkan kerja fisik yang eksplosif. Eksplosif power ditentukan oleh kekuatan otot dan kecepatan rangsangan syaraf serta kecepatan kontraksi"

Menurut Nossek (1982) menyatakan bahwa "Power adalah kemampuan seseorang untuk mengatasi tahanan dengan suatu kecepatan kontraksi otot". Sedangkan menurut Harsono (1988) "Power adalah kemampuan otot untuk mengerahkan kekuatan maksimal dalam waktu yang sangat cepat". Bompa (1990:) mengemukakan bahwa "Power dibedakan dalam dua bentuk yakni power acyclic dan power cyclic". Pembedaan jenis power ini dilihat dari segi kesesuaian jenis latihan atau keterampilan gerak. Dalam kegiatan olahraga power asiklik dan siklik dapat dikenali dari peranannya pada suatu cabang olahraga.

Menurut Radeliffe and Farentinos, (1985), bentuk latihan plyometric dapat meningkatkan explosive power dengan pembagian latihan untuk meningkatkan leg and Hips (Bound, Hops, Jump, Leaps, Skips dan Ricochets), Trunk (Kips, Swings, Twists, Fleksion, dan Extension), dan Upperbody (Presses, Swings, dan Trows). Selanjutnya Bompa (1982) mengatakan bahwa, bentuk bentuk latihan plyometric dikelompokan menjadi dua yaitu: Latihan dengan intensitas rendah (low Impact), Latihan dengan intensitas tinggi (High Impact).

\section{METODE PENELITIAN}

Metode penelitian yang digunakan adalah Desain treatment by level $2 \mathrm{x}$ 2, di mana variabel bebas diklasifikasikan menjadi 2 (dua). bentuk yaitu metode latihan plyometric $\left(\mathrm{A}_{1}\right)$ dan metode latihan beban $\left(\mathrm{A}_{2}\right)$. Sedangkan variabel moderator diklasifikasikan dalam dua tingkatan yaitu kecepatan reaksi tinggi $\left(\mathrm{B}_{1}\right)$ dan kecepatan reaksi rendah $\left(\mathrm{B}_{2}\right)$. Untuk lebih jelasnya dapat dilihat pada tabel di bawah ini. 
Tabel 1

Desain Penelitian

\begin{tabular}{lll}
\hline $\begin{array}{l}\text { Metode } \\
\text { Latihan (A) }\end{array}$ & $\begin{array}{l}\text { Latihan } \\
\text { Plyometric } \\
(\mathrm{A} 1)\end{array}$ & $\begin{array}{l}\text { Latihan } \\
\text { Beban } \\
\mathrm{A} 2)\end{array}$ \\
\hline $\begin{array}{l}\text { Kecepatan } \\
\text { reaksi (B) }\end{array}$ & & \\
\hline Tinggi $\left(\mathrm{B}_{1}\right)$ & $\mathrm{A}_{1} \mathrm{~B}_{1}$ & $\mathrm{~A}_{2} \mathrm{~B}_{1}$ \\
\hline Rendah $\left(\mathrm{B}_{2}\right)$ & $\mathrm{A}_{1} \mathrm{~B}_{2}$ & $\mathrm{~A}_{2} \mathrm{~B}_{2}$ \\
\hline
\end{tabular}

Penelitian ini melibatkan satu variabel bebas yang dimanipulasi, satu variabel bebas yang dikendalikan (atribut), dan satu variabel terikat. Variabel bebas yang dimanipulasi adalah metode latihan yang terdiri dari latihan plyometric dan latihan beban. Variabel bebas yang dikendalikan (atribut) adalah kecepatan reaksi yang terdiri dari kecepatan reaksi tinggi dan kecepatan reaksi rendah. sedangkan variabel terikatnya adalah power otot tungkai pemain bolavoli.

Tempat penelitian dilakukan di lapangan bolavoli Putra di SMA IT IQRO Kota Bengkulu. Waktu penelitian dilaksanakan bulan Mei sampai bulan Juli 2017, selama 6 minggu, dengan frekuensi latihan 3 kali perminggu. Populasi dalam penelitian ini adalah pemain tim ekskul bolavoli Putra SMA IT IQRO kota Bengkulu yang terdaftar dan aktif mengikuti latihan yaitu sebanyak 46 orang, yang terdiri dari 36 orang laki-laki dan 10 orang perempuan. Sampel merupakan wakil dari populasi yang dijadikan responden penelitian. Lebih jelasnya A. Yusuf (2005) menyatakan bahwa "sampel adalah sebagian dari populasi yang terpilih dan mewakili populasi tersebut". Teknik penarikan sampel dilakukan dengan teknik purposive sampling, yaitu dari keseluruhan jumlah populasi yang hanya di ambil menjadi sampel hanya berjumlah 36 orang, peneliti hanya meneliti yang berjenis kelamin laki-laki.

Untuk menyamakan pemahaman terhadap pemakaian istilah atau kata-kata yang dipergunakan dalam penelitian ini, maka perlu memberikan penjelasan definisi operasional sebagai berikut :

1. Latihan plyometric adalah beberapa bentuk latihan untuk meningkatkan daya ledak ( power ) baik untuk daya ledak otot tungkai maupun daya ledak otot lengan. Salah satu bentuk latihan plyometric adalah standing vertical jump, tuck jump, dan but kick jump

2. Latihan beban adalah merupakan latihan dengan memberikan tambahan beban dari luar. Salah satu bentuk latihan beban disini adalah Squad, Leg Extension dan Leg Curl.

3. Kecepatan reaksi adalah kemampuan organisme anak latih untuk menjawab suatu rangsang secepat mungkin dalam mencapai hasil yang sebaik-baiknya.

4. Power otot tungkai adalah kemampuan otot untuk mengerahkan kekuatan maksimal dalam waktu yang sangat cepat.

Instrument adalah alat ukur yang digunakan pada waktu penelitian untuk mendapatkan sebuah data Arikunto (2000). Instrumen penelitian yang digunakan dalam penelitian ini dalah tes Nelson Hand Reaction Test untuk mengukur 
kecepatan reaksi dan tes Vertical Jump untuk mengukur power otot tungkai pemain bolavoli Putra SMA IT IQRO Kota Bengkulu.

1. Nelson Hand Reaction Test meliputi; (a) tujuan. Untuk mengetahui kecepatan reaksi terhadap suatu stimulus, (b) pelaksanaan. Mistar dipegang oleh seorang asisten di antara jari telunjuk dan ibu jari tangan atlet pada tangan yang dominan, maka ibu jari atlet akan sejajar dengan garis $0 \mathrm{~cm}$ pada penggaris. Asisten akan menginstruksikan atlet untuk menangkap penggaris secepat mungkin setelah penggaris dilepaskan, (c) penilaian. Nilai yang tertera merupakan kecepatan reaksi testee dalam centimeter.

2. Tes Vertical Jump meliputi; (a) tujuan. Vertical jump bertujuan untuk mengukur power otot tungkai pemain atau digunakan untuk melihat perkembangan peningkatan power otot tungkai. Alat, alat untuk vertical jump terdiri dari: papan meter jump, kapur, pembersih dan dinding rata, (b) pelaksanaan meliputi; (1) berdiri badan tegak dan tangan lurus ke atas, ukur hasil raihan, (2) melompat dengan power penuh dengan menyentuh papan dan dicatat hasil tinggi raihan. Syarat dalam melakukan vertical jump: berdiri menyamping dinding, setelah mengukur posisi satu, posisi badan tidak boleh berubah waktu akan melakukan loncatan atau tidak ada gerakan tambahan (posisi tubuh merendah), tangan tidak boleh ada gerakan (mengayun) dan ukur berat badan dalam satuan $\mathrm{kg}$.

Variabel dalam penelitian ini terdiri dari variabel bebas (independent) yang terbagi dalam 2 kelompok, variabel moderator (Intervrening) yang terdiri dari 2 tingkatan dan satu variabel terikat (dependent) dengan rincian sebagai berikut:

1. Variabel Bebas (Dependent Variable) dalam penelitian ini adalah metode latihan. Metode latihan yang digunakan sebagai bebas (Dependent Variable) dalam penelitian ini meliputi; (a) metode Latihan Plyometric, (b) metode Latihan Beban.

2. Variabel Moderator (Intervrening Variable). Variabel moderator (Intervrening Variable) dalam penelitian ini adalah kecepatan reaksi, dimana kecepatan reaksi ini terbagi atas dua tingkatan yaitu: (a) kecepatan reaksi tinggi, (b) kecepatan reaksi rendah.

3. Variabel terikat (independent). Variabel terikat (independent variable) dalam penelitian ini adalah power otot tungkai.

Pelaksanaan pengumpulan data dalam penelitian ini dilakukan dengan dua cara yaitu: tes awal (sebelum diberikan perlakuan) kemudian tes akhir (sesudah diberikan perlakuan), hal ini bertujuan untuk melihat pengaruh yang diberikan oleh metode latihan yang digunakan dan kecepatan reaksi yang dimiliki oleh pemain bolavoli Putra SMA IT IQRO Kota Bengkulu terhadap power otot tungkai pemain bolavoli Putra.

Metode analisis data merupakan suatu cara yang ditempuh guna memperoleh atau menganalisa data-data yang diperoleh (Arikunto, 2010). Analisis data bertujuan untuk menguji kebenaran hipotesis yang telah dirumuskan. Teknik analisis data yang digunakan dalam penelitian ini adalah analisis varian (ANOVA) dengan desain eksperimen faktorial $2 \times 2$ dan menggunakan uji lanjut uji Tukey dengan taraf signifikansi $\alpha=0,05$. Sebelum data di analisis dengan menggunakan tekhnik analisis varian (ANOVA), maka dilakukan uji persyaratan analisis sebagai berikut: (1) Uji normalitas menggunakan uji liliefours, untuk 
mengetahui apakah data mempunyai sebaran normal, (2) Uji homogenitas dengan menggunakan uji barlert, hal ini bertujuan untuk mengetahui apakah variansivariansi dari jumlah populasi sama atau tidak, (3) Setalah itu barulah dilakukan uji hipotesis penelitian tekshnik analisis varian (ANOVA) Dua Jalur dan Uji lanjutan yaitu Uji Tukey.

\section{HASIL PENELITIAN}

\section{Power Otot Tungkai Kelompok Latihan Plyometric}

Pengukuran power otot tungkai pada sampel dilakukan dengan menggunakan tes vertcal jump. Tes ini bertujuan untuk melihat seberapa besar power otot tungkai yang dimiliki oleh pemain bolavoli Putra SMA IT IQRO Kota Bengkulu yang dilatih dengan metode laihan plyometric.

Berdasarkan hasil tes vertical jump kelompok latihan plyometric di atas, diperoleh jumlah power otot tungkai kelompok latihan plyometric sebesar 513, rata-rata $=28,50$, standar deviasi $=1,65$, skor tertinggi $=32$, dan skor terendah 26 . Selanjutnya distribusi Frekuensi hasil tes power otot tungkai pemain bolavoli Putra SMA IT IQRO Kota Bengkulu yang dilatih dengan metode latiahan plyometric. pemain bolavoli Putra SMA IT IQRO Kota Bengkulu berada pada kelas rata-rata berjumlah 9 orang dengan persentase 50,00\%. Tidak ada pemain bolavoli SMA IT IQRO Kota Bengkulu yang memiliki skor tes power otot tungkai dibawah rata-rata. Sedangkan skor tes power otot tungkai pemain bolavoli Putra SMA IT IQRO Kota Bengkulu yang berada pada kelas di atas rata-rata berjumlah 9 orang dengan persentase 50,00\%. Untuk lebih jelasnya dapat kita lihat pada diagram di bawah.

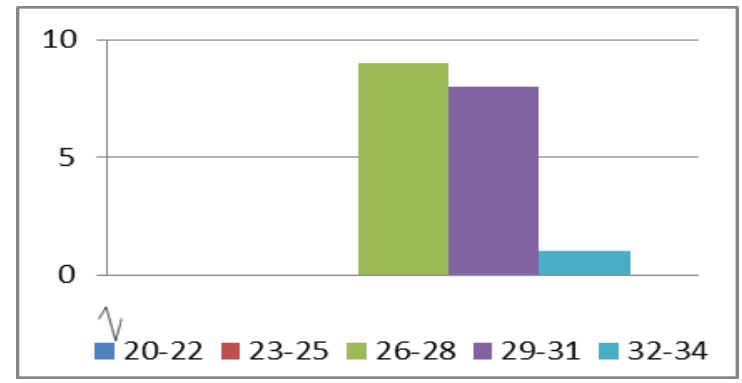

Gambar 1.Histogram frekuensi skor tes Vertical Jump

\section{Power Otot Tungkai Kelompok Latihan Beban}

Pengukuran power otot tungkai pada kelompok latihan ini juga dengan menggunakan tes vertcal jump. Tes ini bertujuan untuk melihat seberapa besar power otot tungkai yang dimiliki oleh pemain bolavoli Putra SMA IT IQRO Kota Bengkulu yang dilatih dengan metode laihan beban.hasil tes vertical jump kelompok latihan beban di atas, diperoleh jumlah power otot tungkai kelompok latihan beban sebesar 488, rata-rata $=27,11$, standar deviasi $=2,68$, skor tertinggi $=32$, dan skor terendah 23. Selanjutnya distribusi Frekuensi hasil tes power otot tungkai pemain bolavoli Putra SMA IT IQRO Kota Bengkulu yang dilatih dengan metode latihan beban.

Power otot tungkai pemain bolavoli Putra SMA IT IQRO Kota Bengkulu yang dilatih dengan menggunakan metode latihan beban, yang berada pada kelas 
rata-rata berjumlah 6 orang dengan persentase 33,33\%, dan yang berada pada kelas dibawah rata-rata berjumlah 6 orang dengan persentase 33,33\%. Sedangkan skor tes power otot tungkai pemain bolavoli Putra SMA IT IQRO Kota Bengkulu yang dilatih dengan metode latihan beban yang berada pada kelas di atas rata-rata berjumlah 6 orang dengan persentase 33,34\%. Untuk lebih jelasnya dapat kita lihat pada diagram di bawah ini.

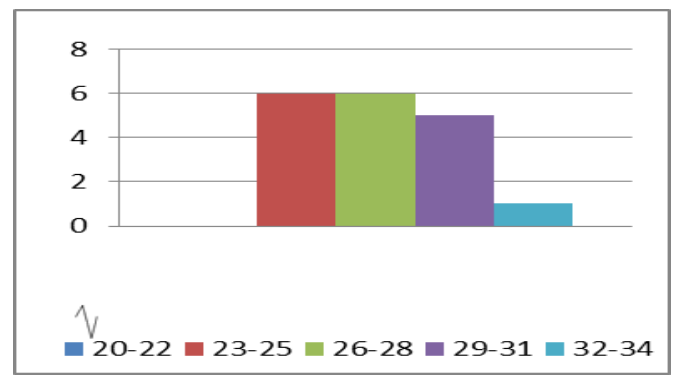

Gambar 2.Histogram frekuensi skor tes Vertical Jump

\section{Tes Kecepatan Reaksi yang Memiliki Kecepatan Reaksi Tinggi (B1)}

Pengukuran kecepatan reaksi menggunakan Nelson Hand Reaction Test. Tes ini bertujuan untuk melihat seberapa tinggi kecepatan reaksi yang dimiliki oleh pemain bolavoli Putra SMA IT IQRO Kota Bengkulu. hasil tes kecepatan reaksi pada kelompok yang memiliki kecepatan reaksi tinggi di atas, diperoleh jumlah sebesar 6,08, rata-rata $=0,34$, standar deviasi $=0,02$, skor tertinggi $=0,30$, dan skor terendah 0,27. Selanjutnya distribusi Frekuensi hasil tes kecepatan reaksi pemain bolavoli Putra.

Kecepatan reaksi pemain bolavoli Putra SMA IT IQRO Kota Bengkulu yang memiliki kecepatan reaksi tingi, yang berada pada kelas rata-rata berjumlah 8 orang dengan persentase $44,44 \%$, dan yang berada pada kelas dibawah rata-rata berjumlah 4 orang dengan persentase 22,22\%. Sedangkan skor tes kecepatan reaksi pemain bolavoli Putra SMA IT IQRO Kota Bengkulu yang yang memiliki kecepatan reaksi tingi yang berada pada kelas di atas rata-rata berjumlah 6 orang dengan persentase $33,33 \%$. Untuk lebih jelasnya dapat kita lihat pada diagram di bawah ini.

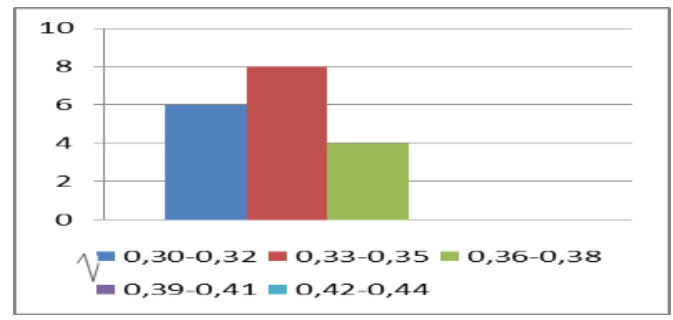

\section{Gambar 3 Histogram frekuensi skor tes kecepatan reaksi kelompok}

\section{Kecepatan Reaksi Yang Memiliki Kecepatan Reaksi Rendah (B2)}

Pengukuran kecepatan reaksi pada kelompok yang memiliki kecepatan reaksi rendah juga menggunakan Nelson Hand Reaction Test. Tes ini bertujuan untuk melihat seberapa tinggi kecepatan reaksi yang dimiliki oleh pemain bolavoli 
Putra SMA IT IQRO Kota Bengkulu. hasil tes kecepatan reaksi pada kelompok yang memiliki kecepatan reaksi tinggi di atas, diperoleh jumlah sebesar 7,08, ratarata $=0,39$, standar deviasi $=0,02$, skor tertinggi $=0,37$, dan skor terendah 0,43.

Selanjutnya distribusi Frekuensi hasil tes kecepatan reaksi pemain bolavoli Putra. Kecepatan reaksi pemain bolavoli Putra SMA IT IQRO Kota Bengkulu yang memiliki kecepatan reaksi rendah, yang berada pada kelas rata-rata berjumlah 10 orang dengan persentase $55,56 \%$, dan yang berada pada kelas dibawah rata-rata berjumlah 2 orang dengan persentase 11,11\%. Sedangkan skor tes kecepatan reaksi pemain bola voli Putra SMA IT IQRO Kota Bengkulu yang yang memiliki kecepatan reaksi tingi yang berada pada kelas di atas rata-rata berjumlah 6 orang dengan persentase 33,33\%. Untuk lebih jelasnya dapat kita lihat pada diagram di bawah ini.

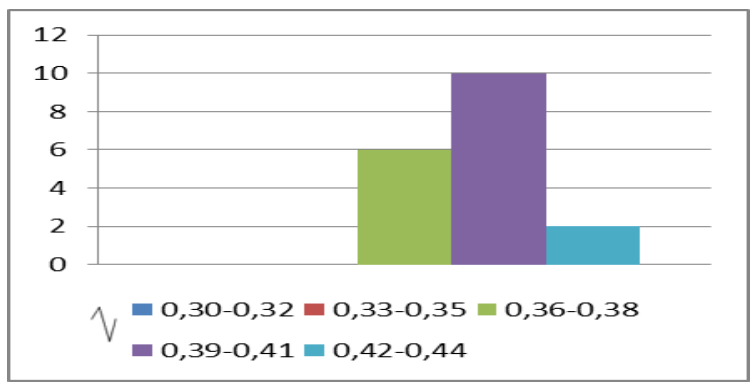

Gambar 4. Histogram frekuensi skor tes kecepatan reaksi kelompok

\section{Power Otot Tungkai Kelompok Latihan Plyometric Yang Memiliki Kecepatan Reaksi Tinggi (A1B1)}

Hasil tes power otot tungkai pemain bolavoli Putra SMA IT IQRO Kota Bengkulu dalam kelompok ini terdiri dari 9 orang diperoleh skor tertinggi 30 dan skor terendah 24 dari kelompok data tersebut diperoleh rata-rata skor 26,22 dan standar deviasi 1,72. power otot tungkai pemain bolavoli Putra SMA IT IQRO Kota Bengkulu dilatih dengan metode latihan plyometric yang memiliki kecepatan reaksi tinggi, yang berada pada kelas rata-rata berjumlah 5 orang dengan persentase $55,56 \%$, dan yang berada pada kelas dibawah rata-rata berjumlah 3 orang dengan persentase 33,33\%. Sedangkan power otot tungkai pemain bolavoli Putra SMA IT IQRO Kota Bengkulu dilatih dengan metode latihan plyometric yang memiliki kecepatan reaksi tingi yang berada pada kelas di atas rata-rata berjumlah 1 orang dengan persentase $11,11 \%$. Untuk lebih jelasnya dapat kita lihat pada diagram di bawah ini.

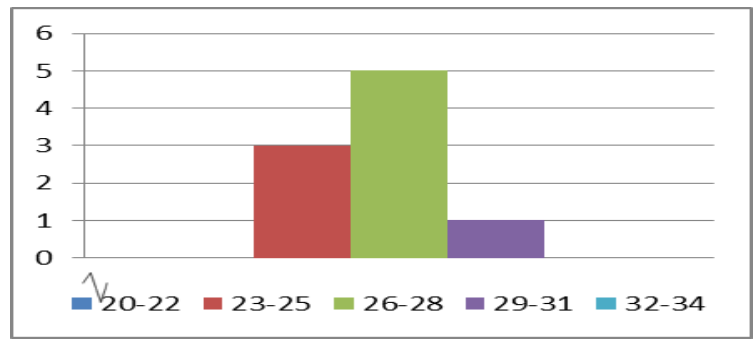

Gambar 5. Histogram frekuensi skor tes power otot tungkai kelompok latihan plyometric yang memiliki kecepatan reaksi tinggi. 


\section{Power Otot Tungkai Kelompok Latihan Plyometric Yang Memiliki Kecepatan Reaksi Rendah (A1B2)}

Hasil tes power otot tungkai pemain bolavoli Putra SMA IT IQRO Kota Bengkulu dalam kelompok ini terdiri dari 9 orang diperoleh skor tertinggi 30 dan skor terendah 26 dari kelompok data tersebut diperoleh rata-rata skor 27,78 dan standar deviasi 1,56.

Power otot tungkai pemain bolavoli Putra SMA IT IQRO Kota Bengkulu dilatih dengan metode latihan plyometric yang memiliki kecepatan reaksi rendah, yang berada pada kelas rata-rata berjumlah 6 orang dengan persentase $66,67 \%$, dan yang berada pada kelas dibawah rata-rata berjumlah 0 orang dengan persentase $0 \%$. Sedangkan power otot tungkai pemain bolavoli Putra SMA IT IQRO Kota Bengkulu dilatih dengan metode latihan plyometric yang memiliki kecepatan reaksi rendah yang berada pada kelas di atas rata-rata berjumlah 3 orang dengan persentase $33,33 \%$. Untuk lebih jelasnya dapat kita lihat pada diagram di bawah ini.

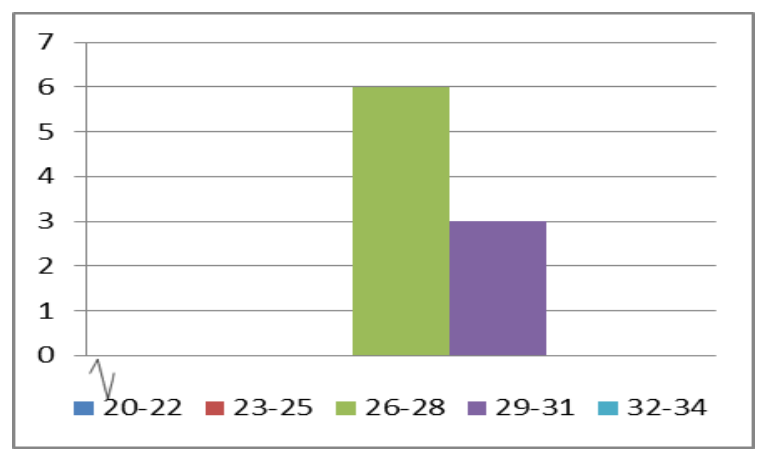

Gambar 6. Histogram frekuensi skor tes power otot tungkai kelompok latihan plyometric yang memiliki kecepatan reaksi rendah.

\section{Power Otot Tungkai Kelompok Latihan Beban Yang Memiliki Kecepatan Reaksi Tinggi (A2B1)}

Hasil tes power otot tungkai pemain bolavoli Putra SMA IT IQRO Kota Bengkulu dalam kelompok ini terdiri dari 9 orang diperoleh skor tertinggi 32 dan skor terendah 27 dari kelompok data tersebut diperoleh rata-rata skor 29,22 dan standar deviasi 1,48.

Power otot tungkai pemain bolavoli Putra SMA IT IQRO Kota Bengkulu dilatih dengan metode latihan beban yang memiliki kecepatan reaksi tinggi, yang berada pada kelas rata-rata berjumlah 5 orang dengan persentase $55,56 \%$, dan yang berada pada kelas dibawah rata-rata berjumlah 3 orang dengan persentase 33,33\%. Sedangkan power otot tungkai pemain bolavoli Putra SMA IT IQRO Kota Bengkulu dilatih dengan metode latihan beban yang memiliki kecepatan reaksi tinggi yang berada pada kelas di atas rata-rata berjumlah 1 orang dengan persentase $11,11 \%$. Untuk lebih jelasnya dapat kita lihat pada diagram di bawah ini. 


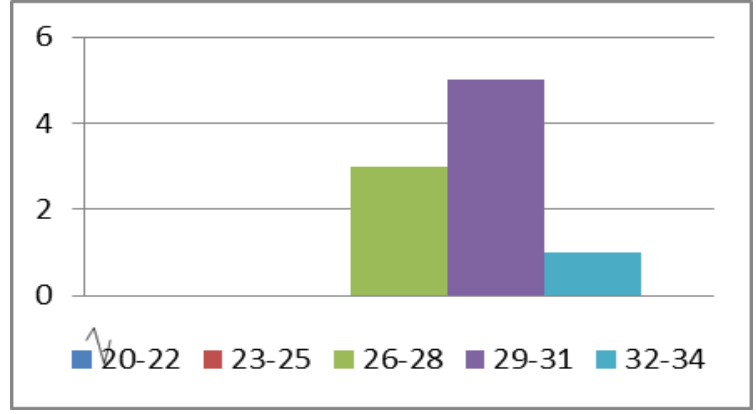

Gambar 7. Histogram frekuensi skor tes power otot tungkai kelompok latihan beban yang memiliki kecepatan reaksi tinggi.

\section{Power Otot Tungkai Kelompok Latihan Beban Yang Memiliki Kecepatan Reaksi Rendah (A2B2)}

Hasil tes power otot tungkai pemain bolavoli Putra SMA IT IQRO Kota Bengkulu dalam kelompok ini terdiri dari 9 orang diperoleh skor tertinggi 28 dan skor terendah 23 dari kelompok data tersebut diperoleh rata-rata skor 25 dan standar deviasi 1,73. power otot tungkai pemain bolavoli Putra SMA IT IQRO Kota Bengkulu dilatih dengan metode latihan beban yang memiliki kecepatan reaksi rendah, yang berada pada kelas rata-rata berjumlah 6 orang dengan persentase $66,67 \%$, dan yang berada pada kelas dibawah rata-rata berjumlah 0 orang dengan persentase $0 \%$. Sedangkan power otot tungkai pemain bolavoli Putra SMA IT IQRO Kota Bengkulu dilatih dengan metode latihan beban yang memiliki kecepatan reaksi rendah yang berada pada kelas di atas rata-rata berjumlah 3 orang dengan persentase 33,33\%. Untuk lebih jelasnya dapat kita lihat pada diagram di bawah ini.

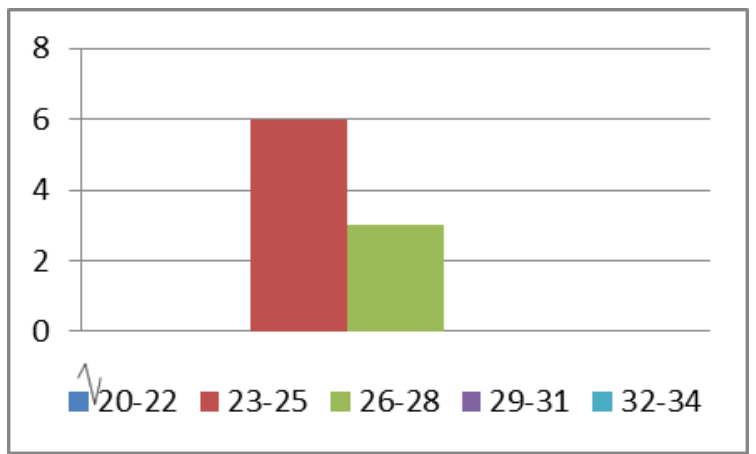

Gambar 8. Histogram frekuensi skor tes power otot tungkai kelompok latihan beban yang memiliki kecepatan reaksi rendah.

Sebelum melakukan pengujian hipotesis dengan menggunakan analisis ANOVA faktorial 2x2 dan uji lanjut dengan uji Tukey. Maka terlebih dahulu uji persyaratan analisis yaitu:

\section{Uji Normalitas Data}

Tujuan melakukan uji normalitas data adalah untuk mengetahui apakah sample berasal dari populasi yang berdistribusi normal, uji yang digunakan adalah uji Liliefors, dengan hipotesis adalah: 
Ho : Sampel berdistribusi normal jika Lo $<\mathrm{Lt}$

H1 : Sampel tidak berdistribusi normal jika Lo $>$ Lt

Uji normalitas data dilakukan untuk setiap rancangan penelitian faktorial 2 $\mathrm{x} 2$. Dari hasil uji normalitas pada ke 8 (delapan) kelompok rancangan penelitian di atas ternyata Lo (observasi) < Lt (table), maka semua kelompok data berdistribusi normal. Dengan demikian syarat pertama uji normalitas yang telah dilakukan untuk menguji hipotesis terpenuhi.

\section{Uji Homogenitas}

Uji homogenitas dilakukan pada masing-masing kelompok data power otot tungkai pemain bolavoli Putra SMA IT IQRO Kota Bengkulu pada taraf signifikan $\alpha=0,05$. Untuk kelompok eksperimen $\mathrm{A} 1, \mathrm{~A} 2$ dan kelompok atribut B1,B2 dilakukan uji homogenitas dengan menggunakan uji varian, sedangkan untuk empat kelompok sel rancangan eksperimen A1B1,A2B1,A1B2,A2B2, dengan menggunakan uji barlet. maka antara $X^{2}$ hitung Kelompok A1,A2 dan B1,B2 Dan A1B1,A1B2,A2B1A2B2 < dari $X^{2}$ tabel, dengan kata lain semua data dari kelompok penelitian berasal dari populasi yang homogen.

Pada dasarnya peneliti sudah berusaha secara maksimal untuk melaksanakan dan mengontrol setiap kegiatan yang ada pada penelitian ini. Meskipun demikian peneliti menyadari bahwa masih terdapat keterbatasan yang dimiliki peneliti dalam melaksanakan penelitian ini yang perlu disampaikan.Penelitian ini hanya mengkaji dua macam metode latihan saja, pada dasarnya masih banyak metode latihan yang cocok diterapkan pada berbagai karakter dan kemampuan yang dimiliki oleh pemain bolavoli. Dalam pelaksaan penelitian ini, peneliti terkadang terkendala oleh faktor cuaca yang tak menentu, namun dengan demikian peneliti berupaya secara maksimal agar tujuan dari penelitian ini dapat tercapai dengan cara mengganti hari peneilitian yang terkendala cuaca tersebut dengan hari lain. Aktifitas fisik dan psikis sampel di luar penelitian ini tidak dapat terkontrol oleh peneliti. Dimana aspek tersebut juga ikut mempengaruhi power otot tungkai yang dimiliki oleh pemain bolavoli.

\section{PEMBAHASAN}

Terdapat Perbedaan Pengaruh Metode Latihan Plyometric dan Metode Latihan Beban terhadap Power Otot Tungkai Pemain Bolavoli

Berdasarkan analisis pengujian hipotesis pertama di atas, dimana Fhitung $=0,58<$ Ftabel $=4,00$. Maka ditemukan bahwa tidak terdapat perbedaan power otot tungkai pemain bolavoli yang dilatih dengan dua metode yang berbeda. Artinya dengan menggunakan du metode ini, secara keseluruhan akan meningkatkan power otot tungkai yang dimiliki oleh pemain bolavoli SMAIT IQRO Kota Bengkulu.

\section{Terdapat Interaksi Antara Metode Latihan dan Kecepatan Reaksi Terhadap Power Otot Tungkai Pemain Bolavoli}

Berdasarkan analisis pengujian hipotesis kedua di atas, dimana Fhitung = $28,39>$ Ftabel $=3,97$. Dalam menggunakan metode latihan yang tepat, maka akan dapat meningkatkan power otot tungkai yang dimiliki oleh pemain bolavoli. Seiring dengan hal tersebut akan terjadi pula peningkatan kecepatan reaksi yang dimilki oleh pemain bolavoli. 
Pemain Bolavoli yang Memiliki Kecepatan Reasksi Tinggi Akan Memiliki Power Otot Tungkai Yang Lebih Baik Jika Dilatih dengan Metode Latihan Beban dari Pada Dilatih Dengan Metode Latihan Plyometric

Berdasarkan analisis pengujian hipotesis ketiga di atas, dimana $\mathrm{Fh}=5,53$ $>\mathrm{Ft}=4,01$, dengan diterimanya hipotesis ketiga ini dapat dilihat, bahwa kecepatan reaksi yang baik, akan membantu pemain bolavoli dalam mencapai tujuan dari latihan yang dilakukan. Bagi pemain yang memiliki kecepatan reaksi tinggi akan lebih mudah mmelatih power otot tungkainya dengan menggunakan metode latihan beban.

\section{Pemain Bolavoli yang Memiliki Kecepatan Reasksi Rendah Akan Memiliki Power Otot Tungkai yang Lebih Baik Jika Dilatih dengan Metode Latihan Plyometric dari Pada Dilatih dengan Metode Latihan Beban}

Berdasarkan analisis pengujian hipotesis keempat di atas, dimana $\mathrm{Fh}=$ $5,12>\mathrm{Ft}=4,01$. Pemain yang memiliki kecepatan reaksi rendah, pada umumnya memerlukan bentuk latihan yang memiliki daya mobilitas tinggi. Sehingga metode latihan plyometric sangat cocok diterapkan untuk pemain yang memiliki kecepatan reaksi rendah. Dengan menggunakan metode latihan plyometric akan sekaligus membantu pemain untuk meningkatkan kecepatan reaksi yang di miliki.

\section{SIMPULAN}

Berdasarkan hasil penelitian yang telah dilakukan, dapat diambil kesimpulan bahwa Tidak terdapat perbedaan hasil power otot tungkai yang dimiliki oleh pemain bolavoli Putra SMA IT IQRO Kota Bengkulu yang dilatih dengan menggunakan metode latihan plyometric dan metode latihan beban. Terdapat interaksi antara metode latihan dan kecepatan reaksi yang dimiliki oleh pemain bolavoli terhadap power otot tungkainya. Maksudnya, melatih power otot tungkai dengan metode latihan plyometric dan metode beban yang tepat akan dapat meningkatkan kecepatan reaksi yang dimiliki oleh pemain bolavoli. Pemain yang memiliki kecepatan reaksi tinggi akan memiliki power otot tungkai yang lebih baik jika dilatih dengan metode latihan beban dari pada metode latihan plyometric. Pemain yang memiliki kecepatan reaksi rendah akan memiliki power otot tungkai yang lebih baik jika dilatih dengan metode latihan plyometric dari pada metode latihan beban.

\section{REFERENSI}

Arikunto, S. (2000). Prosedur penelitian suatu pendekatan praktek. Jakarta:Renika Cipta.

Bompa, O. T. (1990). Theory and methodology of training the key to athletic performance. Dubuque, Iowa: Kendall/Hunt

Bompa, T.,O, (1982).Theory And Methodology Of Training. Dubuge : KendalHunt Publishing Company

Febri, I. (2011). Hubungan Antara Panjang Tungkai, Power Otot Tungkai Dan Kelincahan Terhadap Hasil Lompat Tinggi Gaya Straddle Pada Siswa Putra Kelas V Dan VI SD Negeri 2 Pangempon Kejobong Kabupaten Purbalingga Tahun Pelajaran 2010/2011 Skripsi.UNY 
Harsono. (1988). Coaching dan aspek-aspek psikologis dalam coaching. Jakarta: Dikti P2LPTK.

Nossek, J. (1982). General theory of training. National Institute for Sports, Lagos: Pan African Press.

Radcliffe, J. C. \& Farentinos, R. C. (1985). Plyometrics Explosive Power Training. 2nded. Champaign, Illionis: Human Kinetics Published, Inc.

Sajoto. (1995). Pembinaan Kondisi Fisik Dalam Olahraga. Jakarta: FPOKIKIPSemarang

Siswantoyo. (1996).Sikap dan Gerak Dasar Pencak Silat. Yogyakarta.Universitas Negeri Yogyakarta.

Sudjarwo. (1993). Ilmu Kepelatihan Dasar. Surakarta: Universitas Sebelas Maret Press

Suharsimi, A. (2010). Prosedur Penelitian Suatu Pendekatan Praktek.Jakarta: Rhineka Cipta.

Yusuf, A. (2005). Psikologi Perkembangan Anak dan Remaja. Bandung: remaja Rosdakarya 